\title{
Coral Patch and Ormonde seamounts as a product of the Madeira hotspot, Eastern Atlantic Ocean
}

\author{
Filippo D'Oriano, ${ }^{1,2}$ Lorenzo Angeletti, ${ }^{2}$ Lucilla Capotondi, ${ }^{2}$ Marinella A. Laurenzi, ${ }^{3}$ Matthias López \\ Correa, ${ }^{5}$ Marco Taviani, ${ }^{2}$ Luigi Torelli, ${ }^{4}$ Teresa Trua, ${ }^{4}$ Luigi Vigliotti ${ }^{2}$ and Nevio Zitellini ${ }^{2}$ \\ ${ }^{1}$ Dipartimento di Scienze della Terra e Geologico - Ambientali, Università di Bologna, Piazza di Porta S. Donato 1, 40127 Bologna, Italy; \\ ${ }^{2}$ Istituto di Scienze Marine, CNR, Area della Ricerca di Bologna, Via Gobetti 101, 40129 Bologna, Italy; ${ }^{3}$ Istituto di Geoscienze e Georisorse, \\ CNR, Area della Ricerca di Pisa, Via G. Moruzzi 1, 56124 Pisa, Italy; ${ }^{4}$ Dipartimento di Scienze della Terra, Università degli Studi di Parma, \\ Viale G.P. Usberti 157, 43100 Parma, Italy; ${ }^{5}$ GZN, GeoZentrum Nordbayern, Universität Erlangen-Nürnberg, Loewenichstr. 28, D-91054 \\ Erlangen, Germany
}

\begin{abstract}
New detailed swath bathymetry and bottom samples from Coral Patch and Ormonde seamounts provide constraints on the emplacement of the Madeira hotspot in the Eastern Atlantic Ocean. Swath bathymetric data document that Coral Patch is a composite structure, made up of at least nine distinct volcanic centres. Lithified pelagic carbonates infilling fissures in lava blocks constrain a minimal age for the volcanism in the Early
\end{abstract}

Miocene and represent the first documentation of Coral Patch acting as an offshore terrigenous-starved seamount. At Coral Patch, as already observed at the Ormonde seamount, volcanism was emplaced on top of a pre-existing relief resulting from the regional tectonic compressive regime.

Terra Nova, 22, 494-500, 2010

\section{Introduction}

In the eastern Atlantic, a 700-km-long belt of irregularly spaced seamounts stretches from SW Iberia to the Madeira archipelago (Fig. 1). This trail of seamounts is late Mesozoic to Recent in age and thought to represent the trace of the Madeira hotspot (Morgan, 1981; Geldmacher et al., 2000).

Rocks representing initial and more recent stages of the Madeira hotspot outcrop at the Serra de Monchique complex (c. $72 \mathrm{Ma}$; Miranda et al., 2009) in southern Portugal and at the Madeira and Porto Santo islands (14-0 Ma; Geldmacher et al., 2000), respectively. Knowledge of the submerged portion of the hotspot track is quite scarce, because of the paucity of available bottom samples. Previously collected volcanic samples from the seamounts display an alkaline affinity and a systematic southwestward decrease in age towards Madeira Island (Fig. 1).

Various aspects concerning the style of emplacement, spatial distribution and alignment of these seamounts are still debated (Geldmacher et al., 2005). Indeed, the emplacement of

Correspondence: Filippo D’Oriano, Scienze della Terra e Geologico Ambientali, Università di Bologna, Via Zamboni 67, 40126 Bologna, Italy. Tel.: +390512094546; e-mail: filippo.doriano@ bo.ismar.cnr.it seamounts, particularly those lying east of the proposed hotspot track (i.e. Coral Patch), could be related either to (1) volcanism locally controlled by lithospheric discontinuities or to (2) magmatism related to a weak pulsating plume (Geldmacher et al., 2005; Merle et al., 2006).

The first arrival of the Madeira hotspot probably took place between the Iberian and African plates. However, since the earliest phase of continental break-up, the region has recorded complex plate boundary interactions. Nowadays, NW-SE relative motion between Iberia and Africa is $\sim 4 \mathrm{~mm} \mathrm{a}^{-1}$ (DeMets et al., 1994). The rifting-drifting stage was accompanied by sub-crustal mantle exhumation and scarce volcanism (Boillot et al., 1995; Whitmarsh and Wallace, 2001; Manatschal, 2004; Rovere et al., 2004). From the middle Cretaceous to the Oligocene, Iberia was part of the African Plate, and the Gulf of Cadiz remained unaffected by any important tectonic stress. During the Oligocene, the counterclockwise rotation of Iberia with respect to Africa produced diffuse intraplate compressive deformation in the Gulf of Cadiz (Sartori et al., 1994; GalindoZaldivar et al., 2003). At about 2.0 Ma (Rosas et al., 2009), the deformation started to be localized along a set of ESE-WNW strike-slip faults, the SWIM fault zone (Zitellini et al., 2009; Fig. 1). During this compressive stage, lithospheric folding developed in the area from the Oligocene to Late Pliocene (Burov and Cloetingh, 2009; Zitellini et al., submitted) causing the development in the brittle crust of large synclines bounded by short thrust-top anticlines, coincident with the location of the Coral Patch and Gorringe Bank seamounts.

This work presents new marine geophysical and geological data collected during the SWIM 2004 and SWIM 2005 expeditions in the Atlantic Ocean providing better constraints on the evolution of the Madeira hotspot.

\section{Materials and methods}

During the R/V Urania SWIM 2004 and R/V Explora SWIM 2005 cruises, bathymetric, chirp seismic and bottom sampling data were collected at Coral Patch and Ormonde seamounts (Table 1).

The bathymetric data were processed on board using Kongsberg PDS2000 and with the IFREMER Caraibes software, and at ISMARBologna using Konsberg NEPTUNE software to build a $50 \times 50 \mathrm{~m}$ grid spacing digital terrain model (Fig. 2) for elevation down to $1000 \mathrm{~m}$ bsl and $100 \times 100 \mathrm{~m}$ below $1000 \mathrm{~m}$ bsl.

Volcanics (lavas, volcanic breccia, hyaloclastites) and sedimentary carbonates were recovered from four sampling sites at the Coral Patch and 




Fig. 1 Bathymetry of the Central Eastern Atlantic (Sandwell and Smith, 1997); thin black line: Gibraltar accretionary prism; thick black line: Iberia-Africa plate boundary proposed by Zitellini et al. (2009); transparent line: Madeira hotspot track; black triangles: SWIM samples on the Coral Patch (A) and Ormonde (B) seamounts; SFZ: SWIM fault zone. Age data from the literature are: Monchique plutonic complex 73-72 Ma (MacIntyre and Berger, 1982; Miranda et al., 2009); Ormonde 68-62 Ma (Féraud et al., 1982, 1986); Ampère seamount 31 Ma (Geldmacher et al., 2000); Unicorn and Seine Seamounts 27 and 22 Ma respectively (Geldmacher et al., 2005); Porto Santo Island 14-11 Ma (Geldmacher et al., 2000); Madeira/Desertas Islands volcanic complexes < 5 Ma (Geldmacher et al., 2000). J Anomaly after Olivet (1996).

Table 1 Cruises and instrument technical details.

\begin{tabular}{lll}
\hline Cruise & SWIM 2004 & SWIM 2005 \\
\hline Ship & R/V Urania & R/V Explora \\
Positioning & DGPS Fugro & DGPS LandStar MK Veripos \\
Navigation & Reson PDS2000 & Reson PDS2000 \\
Bathymetry & No & RESON $815012 \mathrm{kHz} 234$ beams \\
CHIRP seismics & $3.5-5 \mathrm{kHz}$ BENTHOSII & No \\
Sampling & Grab 60 L, Dredge 200 kg & No \\
\hline
\end{tabular}

Ormonde seamounts (Figs 1 and 2 and Appendix S1). The main petrographical characteristics of the volcanics were derived by the analysis of thin sections and microprobe analyses carried out on the mineral phase (see Appendices S2 and S3). Microprobe analyses were performed at the IGGCNR, Padova using a CAMECA SX50 electron microprobe.

${ }^{40} \mathrm{Ar}-{ }^{39} \mathrm{Ar}$ step-heating and single crystal analyses were performed on volcanics from Ormonde and Coral
Patch at the Ar-Ar laboratory, IGG-CNR, Pisa (Appendix S4).

Magnetic susceptibility and the Natural Remanent Magnetization were measured on four samples drilled from an un-oriented sample (SWIM04-29/1) using a Bartington MS2 meter and a Molspin spinner magnetometer at the palaeomagnetic laboratory of ISMAR-Bologna.

Biostratigraphical investigation based on Foraminifera was performed on infilling carbonates (SWIM04-29).
Macropalaeontological analysis of loose sediment was performed through wet sieving using 1-, 0.5and $0.063-\mathrm{mm}$ screens; the resulting fractions were then observed using an optical microscope. Hardgrounds were inspected dry using magnifying lenses. Whenever possible, specimens were identified at species level.

\section{Morphobathymetry}

Coral Patch is a WSW-ENE-elongated seamount, with the top at about $645 \mathrm{~m}$ bsl, rising about $4000 \mathrm{~m}$ above the Horseshoe and Seine abyssal plains (Fig. 2). This sub-elliptical seamount is about $120 \mathrm{~km}$ long and $70 \mathrm{~km}$ wide.

Seismic multichannel data (Hayward et al., 1999; Contrucci et al., 2004; Zitellini et al., 2009) show that the Coral Patch is sedimentary in nature, up to $2500 \mathrm{~m}$ bsl. Neverthe- 


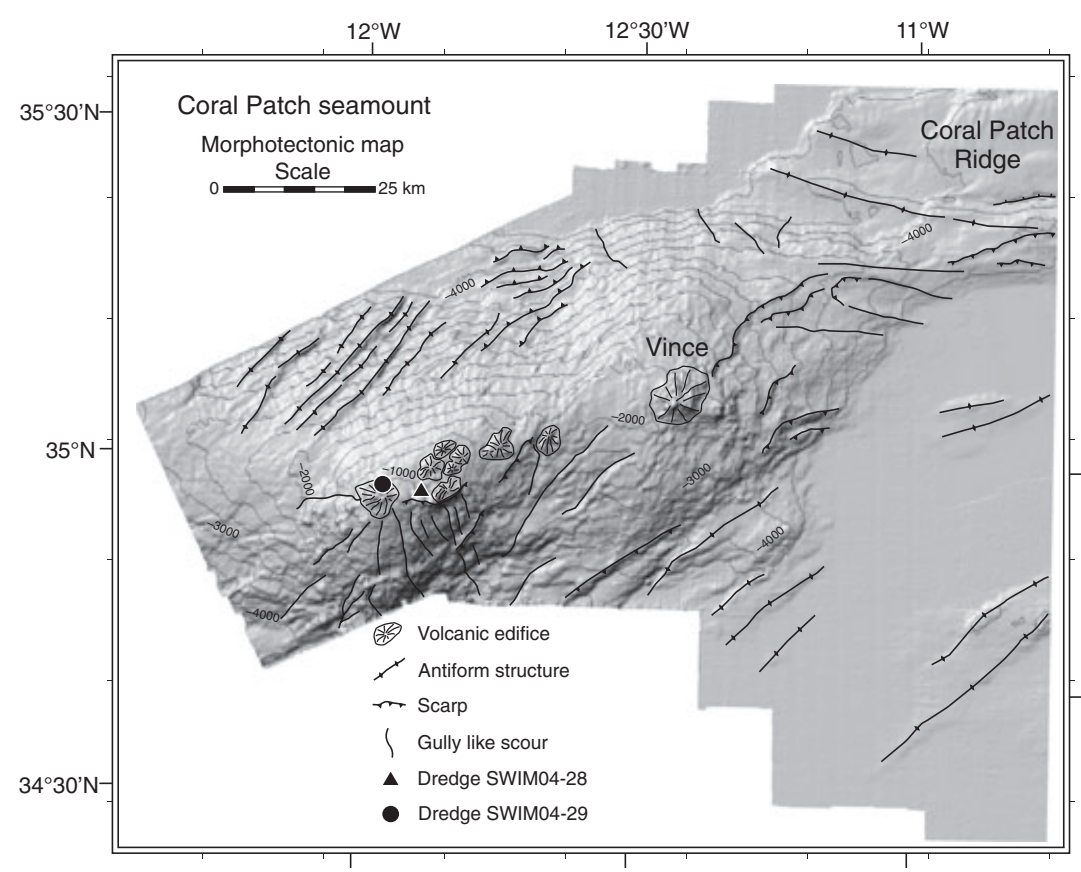

Fig. 2 Shaded relief map of the SWIM 2005 survey, with superimposed morphological and structural interpretation (Appendix S5). Contour steps: $250 \mathrm{~m}$. gravitational collapse or mass-wasting phenomena.

The northern sector of Coral Patch is more complex. On its eastern side, the slope dips gently towards the Horseshoe Abyssal Plain and only linear, small scours are developed along it. The central sector is characterized by a flat topography in the shallower part and by a series of subparallel North-verging scarps in the deeper part, again most likely caused by gravitational phenomena. The western side is characterized by the presence of a series of sub-parallel ridges, oriented NE-SW, $15-30 \mathrm{~km}$ long, 2-3 km wide and $\sim 100 \mathrm{~m}$ high. These are anticline folds as documented by the CD seismic reflection line reported in Hayward et al. (1999).

\section{Petrography and palaeomagnetism}

At Coral Patch, a large block of breccia, up to $30 \mathrm{~cm}$ in diameter (Fig. 3), was dredged from one of its major less, at shallower levels, volcanic rocks are present, as documented by ROV visual inspection (Hebbeln, 2008), samples (Geldmacher and Hoernle, 2000) and this study.

Swath bathymetric data (Fig. 2) document the presence of several coalescent volcanic edifices emplaced on the upper part of the Coral Patch seamount. Nine principal volcanic centres have been identified, eight of which are clustered on the southwestern margin, while a single isolated cone (Vince volcano: Fig. 2) arises $450 \mathrm{~m}$ from the north-eastern side. All the minor volcanic edifices are about 3-5 km wide and 100-300 $\mathrm{m}$ high, whereas Vince volcano is larger, reaching a diameter of about $8 \mathrm{~km}$. The volcanic edifices are easily recognizable by their sub-circular conic shape and well-preserved volcanic morphologies such as radially spread out elongated lava flows on their slopes.

The western slope of the Coral Patch gently declines, joining with the eastern slope of Ampère Seamount, while the south-eastern slope is steeper with inclinations ranging from $5^{\circ}$ to $20^{\circ}$. East of Vince volcano, the slope becomes less steep and is characterized by several scarps, preferentially elongated NNE-SSW, representing the head-scarps of important
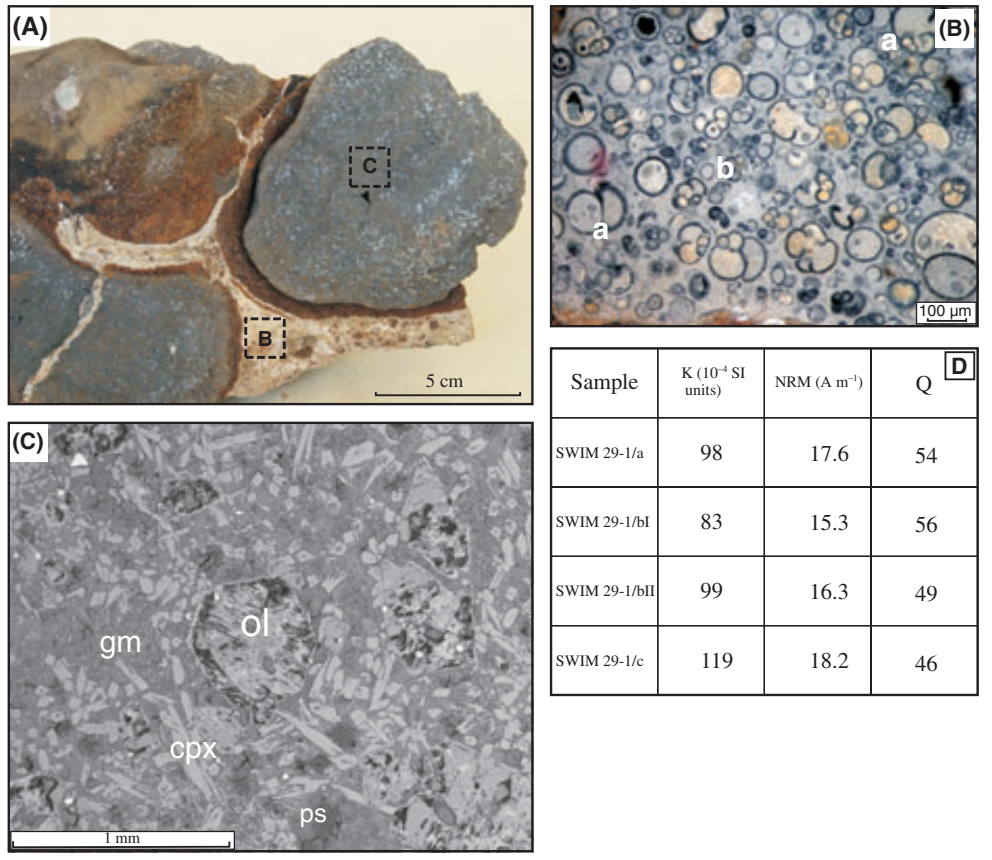

\begin{tabular}{|c|c|c|c|}
\hline Sample & $\begin{array}{c}\text { K (10-4 SI } \\
\text { units })\end{array}$ & NRM $\left(\mathrm{A} \mathrm{m}^{-1}\right)$ & $\mathrm{Q} \mathbf{D}$ \\
\hline SWIM 29-1/a & 98 & 17.6 & 54 \\
\hline SWIM 29-1/bI & 83 & 15.3 & 56 \\
\hline SWIM 29-1//II & 99 & 16.3 & 49 \\
\hline SWIM 29-1/c & 119 & 18.2 & 46 \\
\hline
\end{tabular}

Fig. 3 Samples dredged at station SWIM04-29 on the Coral Patch seamount (coordinates in Appendix S1). (A) Lava blocks infilled by bioclastic sediments. (B) planktic assemblage: (a) Globoquadrina aff. dehiscens (primitive forms); (b) Globorotalia ex gr opima nana/mayeri. (C) SEM photo (in back-scattered electrons) of one lava block. ol=olivine, $\mathrm{cpx}=$ clinopyroxene; $(\mathrm{ps})=$ pseudomorphs, having the shape of feldspathoids, composed of aggregate of zeolites and carbonate; gm = groundmass. (D) Magnetic parameters measured in four samples from Coral Patch: natural remanent magnetization (NRM), magnetic susceptibility (K), Koenigsber ratio (calculated using a value of $41870 \mathrm{nT}$ for the magnetic field). 
volcanic edifices (SWIM04-29; Fig. 2). The block consists of decimetre-sized altered lava fragments cemented by sediments. From this station, hyaloclastites and sediment fragments were also recovered (see Appendix S2). A second dredge (SWIM04-28; Fig. 2) was located on a saddle of the seamount, recovering several limestone fragments and one small volcanic fragment.

Four volcanic fragments were sampled from Ormonde seamount: three are from the SWIM04-32 and one from the SWIM04-34 dredge station.

The high degree of alteration of the studied volcanic samples, evidenced by veins, fractures and vesicles filled with carbonates and/or zeolites, precludes conventional whole-rock analyses, necessary to classify the volcanic rocks properly. Therefore, the magmatic affinity of these samples is derived through mineralogical criteria. The lava fragments from the Coral Patch breccia are olivine-phyric lavas containing phenocrysts of olivine $\left(\mathrm{Fo}_{83-81}\right)$, and diopside clinopyroxene $\left(\mathrm{Wo}_{47-50}-\mathrm{En}_{29-39}\right)$. This assemblage is similar to the basaltic rocks recorded from the nearby Ampère seamount (Geldmacher and Hoernle, 2000) and provides new knowledge on the regional magmatism previously known to include only hawaiitic lavas (Geldmacher and Hoernle, 2000).

The four lava fragments from the Ormonde seamount resemble highly alkaline, silica-undersaturated volcanics (lamprophyres and phonolites) previously documented from this seamount (Corner, 1982; Geldmacher and Hoernle, 2000; Schärer et al., 2000). In detail, samples SWIM0432/1, SWIM04-32/2 and SWIM04$32 / 3$ show mineralogical assemblages similar to the lamprophyric dykes cutting the north-eastern part of the seamount (Corner, 1982). These rocks are porphyric with altered olivine and diopsidic clinopyroxene $\left(\mathrm{Wo}_{47-52^{-}}\right.$ $\left.\mathrm{En}_{26-41}\right)$ phenocrysts set in a groundmass consisting of these phases plus altered feldspar, biotite, opaques and altered glass. Sample SWIM04-34 is similar to the phonolites; it has rare phenocrysts of a sodalite-group mineral and resorbed biotite set in a microlitic fluidal groundmass consisting of these phases plus altered nepheline, feldspar, opaques and altered glass.

Palaeomagnetic analysis was performed on four volcanic samples from the volcanic breccia sample SWIM04-29/1 (Fig. 3D). In spite of the alteration, both susceptibility and remanence are quite high, indicating that the weathering observed in the rock was not able to reset significantly the iron oxides responsible for the magnetic parameters. However, some scatterings, observed especially in the susceptibility, which ranges between 83 and $119 \times 10^{-4}$ SI units, can be confidently attributed to post-depositional alteration. The magnetization intensity exhibits a mean value of $16.3 \mathrm{~A} \mathrm{~m}^{-1}$. By considering a value of $41870 \mathrm{nT}$ for the magnetic field at the site, a Koenigsberger ratio between 46 and 56 has been calculated, clearly indicating the dominance of the remanence on the induced magnetization. This magnetic anomaly, which never exceeds a value of $200 \mathrm{nT}$, may reflect the role of weathering on magmatic properties.
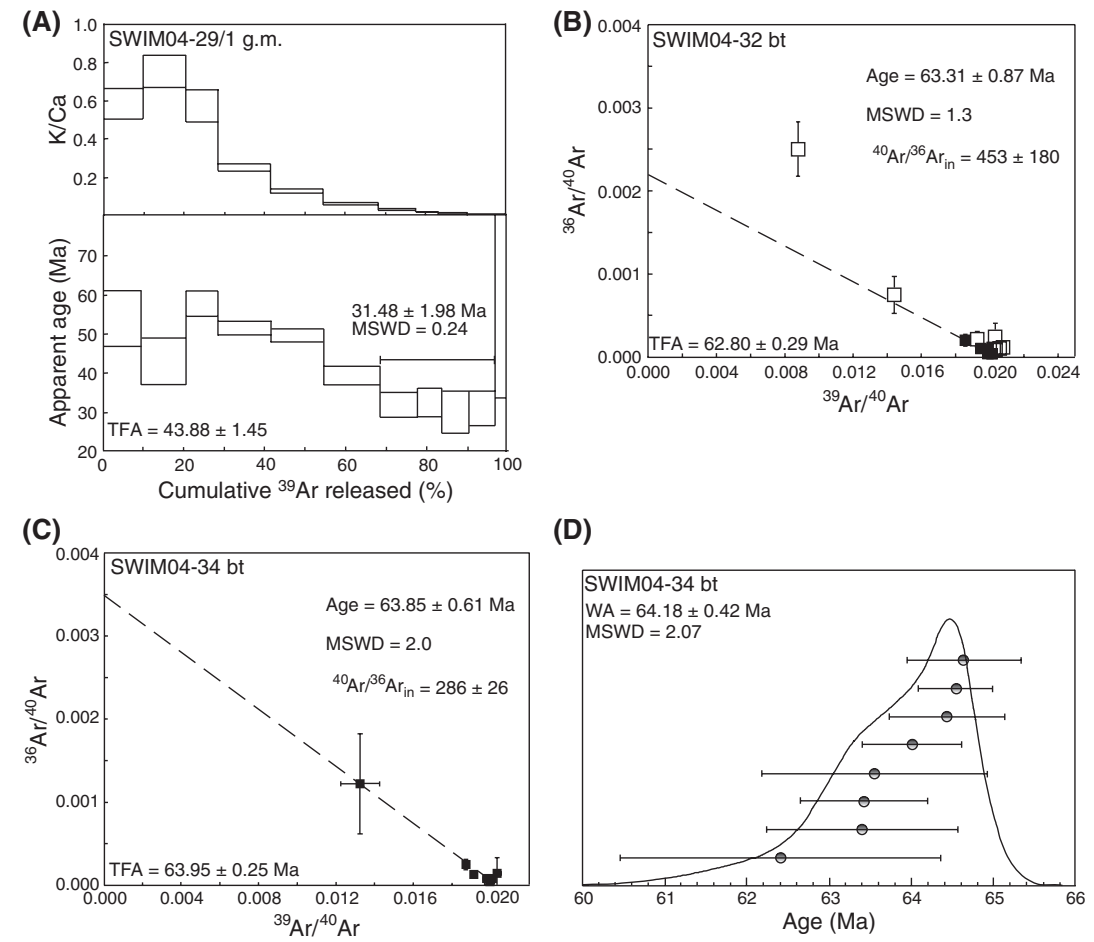

(D)



Fig. $4{ }^{40} \mathrm{Ar}-{ }^{39} \mathrm{Ar}$ geochronology. Errors are quoted at the $\pm 2 \sigma$ level. (A) ${ }^{40} \mathrm{Ar}-{ }^{39} \mathrm{Ar}$ apparent age and related K/Ca spectra of the groundmass of sample SWIM04-29/1 vs. the cumulative percentage of ${ }^{39} \mathrm{Ar}$ released. Error boxes are $\pm 2 \sigma$. The horizontal bar indicates the steps used to calculate the plateau age. TFA, total fusion age. MSWD, Mean square of Weighted Deviates. (B) ${ }^{36} \mathrm{Ar} /{ }^{40} \mathrm{Ar}$ vs. ${ }^{39} \mathrm{Ar} /{ }^{40} \mathrm{Ar}$ isotope correlation diagram for sample SWIM04-32/3: solid squares represent the steps used to calculate the isochron age $\left(41.7 \%\right.$ of ${ }^{39} \mathrm{Ar}$ release), empty squares are all the other points. ${ }^{40} \mathrm{Ar} /{ }^{36} \mathrm{Ar}_{\text {in }}=$ initial ${ }^{40} \mathrm{Ar} /{ }^{36} \mathrm{Ar}$ ratio. (C) Isotope correlation diagram for sample SWIM04-34 on $100 \%$ of ${ }^{39} \mathrm{Ar}$ released. Legend as in (B). (D) Single crystals laser total fusion experiments: age data points $( \pm 2 \sigma)$ and related probability plot. WA, weighted average age. 
mini-plateau at about $31.5 \mathrm{Ma}$ $\left(28.4 \%\right.$ of ${ }^{39} \mathrm{Ar}$ release) of questionable meaning; however, the date is within error equal to the age of the nearby Ampère seamount (Geldmacher et al., 2000).

At Ormonde, two biotites (SWIM0432 and SWIM04-34) display a moderately and a slightly disturbed age spectra respectively (see Appendix S4). Isochron calculations performed on mini-plateau steps (SWIM04-32; Fig. 4 B) and all steps (SWIM04-34; Fig. 4C) give concordant age data, within error equal to their respective total fusion ages. Single crystal laser total fusion analyses of SWIM04-34 biotites (Fig. 4 D) further support an age of about $64 \mathrm{Ma}$ for the Ormonde samples, consistent with ages reported in the literature (62-68 Ma; Féraud et al., 1982, 1986).

\section{Bio-sedimentological analysis}

Some dredging and grab samples were obtained from the flanks and tops of the two edifices of Coral Patch and Ormonde (Fig. 2). They include freshly detached slabs of olivine-phyric lavas (Fig. 5A), carbonate firm- and hardgrounds often patinated by $\mathrm{Fe}-\mathrm{Mn}$ oxides and affected by intense bioerosion (Fig. 5B), and Late Quaternary palimpsest loose skeletal hash and coarse sand (Fig. 5G). Hard-grounds provide a substrate for encrusting epifauna (mainly serpulids, corals, hydroids, e.g. Sertularella sp.; Fig. 5F). Deep-water corals are also frequent (e.g. Madrepora oculata) often making framestones that encase skeletal remains (e.g. gastropods and pteropods, Fig. 5C-5E). Skeletal assemblages (Fig. 5G) consist of benthic (e.g. bivalves, gastropods, corals, brachiopods) and holoplanktic (e.g. thecosomatous pteropods, heteropods) biosomes and bioclasts. Lithified and unlithified carbonates are consistent with a persistent deep-water aphotic setting under the influence of strong bottom currents.

\section{Discussion and conclusion}

The new data presented here provide evidence of at least nine distinct well-preserved coalescent volcanic cones located on top of Coral Patch. These cones were emplaced on a pre-existing sedimentary structural high.


Fig. 5 Various types of sedimentary products sampled from Coral Patch seamount: (A) Sliced slab of the olivine-phyric sample (st. SWIM04-29) reported in Fig. 3A; note fouling recent epifauna, including serpulid tubes (s) and an undetermined solitary coral base (c). (B) Carbonate hardground from st. SWIM04-28,958/725m; the fresh cut shows many elongated vugs due to dissolution of former deep-water coral branches; the external surface is blackened by an $\mathrm{Mn}-\mathrm{Fe}$ oxide coating and affected by intense bioerosion (Trypanites - ichnofacies). (C) Carbonate hard-ground recovered at st. SWIM04-28, showing different stages of lithification. (D) Close-up of the sample in 5.3, displaying coarse skeletal components entrapped in a poorly lithified matrix, including benthic (g) (Amphissa acutecostata) and holoplanktonic (h) gastropods, deep-water branching corals (m) (Madrepora oculata) and others. (E) Coarse coral frame bearing hard-ground made up of degraded and bioeroded Madrepora, st. SWIM04-28. (F) Living hydroid (Sertularella sp., identification courtesy of G. Bavestrello) growing on carbonate coral rubble (st. SWIM04-28). (G) Palimpsest skeletal assemblage from st. SWIM04-28; coarse coral-mollusc hash is mostly composed of more or less degraded shell material, including molluscs $(\mathrm{b}=$ the bivalve Asperarca $)$, brachiopods $(\mathrm{t}=$ Terebratula $)$, corals $(\mathrm{c}=$ Deltocyathus sp.), barnacles, serpulids, echinoids, etc.

The strongly altered basaltic lava fragments of the Coral Patch volcanic breccia sample failed to produce a self-consistent ${ }^{40} \mathrm{Ar}-{ }^{39} \mathrm{Ar}$ age determination, but the Early Miocene age of the sedimentary infilling provides a minimum age for the emplacement of volcanism in the area. By comparing our petrological data with previously published results (Geldmacher et al., 2006), we find that the magmatism affecting Coral Patch has a basaltichawaiite range, comparable with that observed at the Ampère Seamount (Geldmacher and Hoernle, 2000). Systematic variation in the chemical composition of Ampère lavas has been related to different degrees of partial melting above discrete pulses of a mantle plume (Geldmacher and Hoernle, 2000). We argue here that a similar process could also control the 
basaltic-hawaiite variation observed in the Coral Patch lavas, although more samples are required to support this claim confidently.

Zitellini et al. (unpublished data) suggest that the whole sector of the Eurasia-Africa plate boundary has been affected by lithospheric folding since the Oligocene. This implies an overlap of the two processes: oblique lithospheric collision and hotspot-related volcanism.

Burov and Cloetingh (2009) show how lithospheric folding in a low convergence rate $\left(<1.5 \mathrm{~cm} \mathrm{a}^{-1}\right)$ area having a relatively young $(<150 \mathrm{Ma})$ lithosphere can occur only if an external perturbation, such as a mantle plume, is also present and how this may result in a reduction in the folding wavelength of the overlying lithospheric plate. In the Gulf of Cadiz, lithospheric folding is manifested in a confined region near the plate boundary and above the hotspot track; thus, folding and thrusting in this area were probably influenced by the plume emplacement. The facts that all the seamounts of the area (Gorringe, Coral Patch and Ampère seamounts) are ENE-WSW-oriented, in response to regional compression, and that all of them show evidence on their tops of the Madeira hotspot trail suggest that magmatism affecting these structures is strictly correlated with the propagating lithospheric compressive fracture.

In our hypothesis, the lithospheric folding processes formed elongated lithospheric discontinuities, which should have acted as preferential paths for the upwelling of mantle material, thus accounting for both the irregularly spaced hotspot seamounts, with large kilometre-sized gaps in between, and the WSW-ENE orientation of the volcanic centres at the Coral Patch, Ampère and Ormonde seamounts.

\section{Acknowledgements}

We thank the Captains, crew and technical staff of the Research Vessels for their assistance during the cruises, Giovanni Bortoluzzi for technical and software support, M. Lòpez Correa and Alessandro Ceregato for their help during the cruise SWIM04, Andrea Comelli for thin section preparation, Luca Barchi for SEM technical support, Raul Carampin for assistance during the electron microprobe analyses and Cristian Carli for microanalytical work. We thank Editor Jason Phipps Morgan, Joerg Geldmacher and an anonymous reviewer. We acknowledge the financial support from the projects NEAREST (contract no. 0371109) and HERMIONE (contract no. 226354). This work is ISMARBologna scientific contribution no.1657.

\section{References}

Berggren, W.A., Kent, D.V., Swisher, C.C., III and Aubry, M.-P., 1995. A revised Cenozoic geochronology and chronostratigraphy. In: Time Scales and Global Stratigraphic Correlation (W.A. Berggren and D.V. Kent, eds). SEPM Spec. Publ., 54, 129-218.

Boillot, G., Beslier, M.O. and Girardeau, J., 1995. Nature, structure and evolution of the ocean-continent boundary: the lesson of the West Galicia margin (Spain). In: Rifted Ocean-Continent Boundaries (E. Banda, M. Torné and M. Talawani, eds). The Netherlands: Kluwer Academic, pp. 219-229.

Bolli, H.M. and Saunders, J.B., 1985. Oligocene to Holocene low latitude planktic foraminifera. In: Plankton Stratigraphy (H.M. Bolli, J.B. Saunders and K. Pearch Nielsen, eds). Cambridge: Cambridge University Press, pp. 155-262.

Burov, E. and Cloetingh, S., 2009. Controls of mantle plumes and lithospheric folding on modes of Intraplate continental tectonics: differences and similarities. Geophys. J. Int., 178, 1691-1722.

Contrucci, I., Klingelhöfer, F., Perrot, J., Bartolome, R., Gutscher, M.A., Sahabi, M., Malod, J. and Rehault, J.P, 2004. The crustal structure of the NW Moroccan continental margin from wide-angle and reflection seismic data. Geophys. J. Int., 159, 117-128.

Corner, G., 1982. Petrology of the alkaline volcanism of Gorringe Bank (southwest Portugal). Mar. Geol., 47, 101-130.

DeMets, C., Gordon, R.G., Argus, D.F. and Stein, S., 1994. Effect of recent revisions to the geomagnetic reversal time scale on estimates of current plate motions. Geophys. Res. Lett., 21, 2191-2194.

Féraud, G., Gastaud, J., Auzende, J.M., Olivet, J-L. and Cornen, G, 1982. ${ }^{40} \mathrm{Ar} /{ }^{39} \mathrm{Ar}$ ages of the alkaline volcanism and the basement of Gorringe Bank, North Atlantic ocean. Earth Planet. Sci. Lett., 57, 211-226.

Féraud, G., York, D., Mével, C., Cornen, G., Hall, C.M. and Auzende, J-M., 1986. Additional ${ }^{40} \mathrm{Ar}-{ }^{39} \mathrm{Ar}$ dating of the basement and the alkaline volcanism of Gorringe Bank (Atlantic Ocean). Earth Planet. Sci. Lett., 79, 255-269.
Galindo-Zaldivar, J., Maldonado, A. and Schreider, A.A., 2003. Gorringe Ridge gravity and magnetic anomalies are compatible with thrusting at a crustal scale. Geophys. J. Int., 153, 586-594.

Geldmacher, J. and Hoernle, K., 2000. The $72 \mathrm{Ma}$ geochemical evolution of the Madeira Hotspot (eastern North Atlantic); recycling of Paleozoic ( $\leq 500 \mathrm{Ma})$ oceanic lithosphere. Earth Planet. Sci. Lett., 183, 73-92.

Geldmacher, J., Bogaard, P.v.d., Hoernle, K. and Schmincke, H.U., 2000. The ${ }^{40} \mathrm{Ar} /{ }^{39} \mathrm{Ar}$ age dating of the Madeirs Archipelago and hot spot track (eastern North Atlantic). Geochem. Geophys. Geosyst., 1, 1008, doi:10.1029/1999GC0 00018.

Geldmacher, J., Hoernle, K., Bogaard, P.v.d., Duggen, S. and Werner, R., 2005. New ${ }^{40} \mathrm{Ar} /{ }^{39} \mathrm{Ar}$ age and geochemical data from seamounts in the Canary and Madeira volcanic provinces: support for the mantle plume hypotesis. Earth Planet. Sci. Lett., 237, 85-101.

Geldmacher, J., Hoernle, K., Klügel, A., Bogaard, P.v.d., Wombacher, F. and Berning, B., 2006. Origin and geochemical evolution of the Madeira-Tore Rise (eastern North Atlantic). J. Geophys. Res., 111, B09206, doi:10.1029/ 2005JB003931.

Hayward, N., Watts, A.B., Westbrook, G.K. and Collier, J.S., 1999. A seismic reflection and GLORIA study of compressional deformation in the Gorringe Bank region, eastern North Atlantic. Geophys. J. Int., 138, 831-850.

Hebbeln, D., 2008. Short Cruise Report, Expedition 64PE284 R/V Pelagia. Available at: http://www.ifm.zmaw.de (accessed on 4 November 2009).

MacIntyre, R.M. and Berger, G.W., 1982. A note on the geochronology of the Iberian Alkaline Province. Lithos, 15, 133-136.

Manatschal, G., 2004. New models for evolution of magma-poor rifted margins based on a review of data and concepts from West Iberia and the Alps. Int. J. Earth Sci. (Geol. Rundsch.), 93, 432-466.

Merle, R., Schrarer, U., Girardeau, J. and Corner, G., 2006. Cretaceous seamounts along the continent - ocean transition of Iberian margin; $\mathrm{U}-\mathrm{Pb}$ ages and $\mathrm{Pb}-\mathrm{Sr}-$ $\mathrm{Hf}$ isotopes. Geochim. Cosmochim. Acta, 70, 4950-4976.

Miranda, R., Valadares, V., Terrinha, P., Mata, J., Azevedo, M. d. R., Gaspar, M., Kullberg, J.C. and Ribeiro, C., 2009. Age constraints on the Late Cretaceous alkaline magmatism on the West Iberian Margin. Cretaceous Res., 30, 575-586.

Morgan, W.J., 1981. Hotspot tracks and the opening of the Atlantic and Indian Oceans. In: The Sea: Oceanic Lithosphere, Vol. 7 (C. Emiliani, ed.), pp. 443-487. John Wiley, New York. 
Olivet, J.-L., 1996. La cinématique de la plaque Ibérique. Bull. Centres Rech. Explor.-Prod. Elf-Aquitaine, 20, 131-195.

Rosas, F.M., Duarte, J. and Terrinha, P., Valadares, V., Matias, L. and Gutscher, M.-A., 2009. Major bathymetric lineaments and soft sediment deformation in NW Gulf of Cadiz (Africa-Iberia plate boundary): new insights from high resolution multibeam bathymetry data and analogue modelling experiments. Mar. Geol., 261, 33-47.

Rovere, M., Ranero, C.R. and Sartori, R., Torelli, L. and Zitellini, N., 2004. Seismic images and magnetic signature of the Late Jurassic to Early Cretaceous Africa-Eurasia plate boundary off SW Iberia. Geophys. J. Int., 158, 554-568.

Sandwell, D.T. and Smith, W.H.F., 1997. Global sea floor topography from satellite altimetry and ship depth soundings. Science, 277, 1956-1962.

Sartori, R., Torelli, L., Zitellini, N., Peis, D. and Lodolo, E., 1994. Eastern segment of the Azores-Gibraltar line (central-eastern Atlantic): An oceanic plate boundary with diffuse compressional deformation. Geology, 22, 555-558.
Schärer, U., Girardeau, J., Cornen, G. and Boillot, G., 2000. 138-121 Ma asthenospheric magmatism prior to continental break-up in the North Atlantic and geodynamic implications. Earth Planet. Sci. Lett., 181, 555-572.

Whitmarsh, R. B. and Wallace, P.J., 2001. The rift-to-drift development of the West Iberia nonvolcanic continental margin: A summary and review of the contribution of ocean drilling program leg 173. In: Proceedings of the Ocean Drilling Program, Scientific Results. (M.O. Beslier, R.B. Whitmarsh, P.J. Wallace and J. Girardeau, eds) College Station, TX, 173, pp 1-36

Zitellini, N., Gràcia, E., Gutscher, M.A., Matias, L., Masson, D., Mulder, T., Terrinha, P., Somoza, L., DeAlteriis, G., Henriet, J.P., Dañobeitia, J.J., Ramella, R., Abreu, M.A. and Diez, S., 2009. The quest for the Iberia-Africa Plate boundary west of Gibraltar. Earth Planet. Sci. Lett., 280, 13-50.

Received 6 November 2009; revised version accepted 16 August 2010

\section{Supporting Information}

Additional Supporting Information may be found in the online version of this article:

Appendix S1. Sampling station coordinates, typology of sampling and recovery sample used in this work from SWIM 2004 cruise.

Appendix S2. Main petrographic features of the studied samples.

Appendix S3. Mineral chemistry of the studied samples.

Appendix S4. ${ }^{40} \mathrm{Ar}-{ }^{39} \mathrm{Ar}$ dating.

Appendix S5. 3-D shaded relief of the Coral Patch Seamount.

Please note: Wiley-Blackwell is not responsible for the content or functionality of any supporting materials supplied by the authors. Any queries (other than missing material) should be directed to the corresponding author of the article. 